\title{
IMPROVING STUDENTS' ACHIEVEMENT IN NARRATIVE WRITING THROUGH CONSULTANCY PREWRITING PROTOCOL
}

\author{
Rafita Tioria Sianipar \\ Institut Agama Kristen Negeri Tarutung \\ Email: fitasianipar@gmail.com
}

\begin{abstract}
This study attempted to improve students' achievement in narrative writing by applying Consultancy Prewriting Protocol Technique. This study was conducted by using classroom action research. The subject of this research was the students of second year of one of senior high schools in Medan with the total of 43 students. The research was conducted into two cycles consisted of six meetings. The instruments for collecting the data were tests, diary notes, observation sheets, and interview. Based on the data analysis, the mean of the students' score for the orientation test was 52.51, for test I (cycle 1) was 61.39 and for test II (cycle 2) was 76.58. The conclusion is Consultancy Prewriting Protocol Technique can improve the students' achievement in narrative writing.
\end{abstract}

Keywords: Students achievement, narrative writing, Consultancy Prewriting Protocol

\section{A. INTRODUCTION}

\section{Background}

There are four kinds of language skills supposed to be acquired by the students: speaking, listening, reading, and writing. These skills are the objectives of teaching and learning English as a foreign language and they are related to one another. The skills themselves cannot be separated because they give contribution to one another. Writing is one of the most important skills in language learning. Being able to write is a vital skill for speakers of a foreign language as much as for everyone using their own first language (Harmer, 2004:3; see also Graham, Fitzgerald, Friedrich, Greene, Kim \& Olson, 2016). Teaching this skill needs a good preparation of the teacher. To reach the nature of teaching such as mentioned above, it is important to be aware the approach of teaching, method of teaching, technique of teaching, and even the material of teaching. It is expected that all of these things are appropriate, interesting, and meaningful for the students. For instance, in teaching writing an English teacher has to apply a good and appropriate technique, because writing is an extraordinary complex that incorporates thought process, feelings, and social interaction (Graham, MacArthur, and Fitzgerald: 2007).
Writing is actually helpful for the students to learn a language because writing provides many advantages, namely: writing reinforces the grammatical structures, idioms, and vocabulary; writing also enhances the students to adventure the language; by writing the students become very involved with the language effort to express their ideas. Nevertheless, students are not required only to be able to write, but to make a good writing. This happens since "good writing is fundamentally good thinking that follows a logical path and is easy for someone to follow (Bradford, 2019).

As generally known that writing is not merely putting down words or sentences in the form of paper instantly, but it is a thinking process. In order to be able to produce a good writing, students should be able to follow the accurate language use, think as they write, and provoke the language development as they resolve problems when they put their ideas into the written form. In addition, writing requires extensive self- regulation and attention control as stated in Graham \& Harris (2000) in their researches discovered that students fail to do writing. Some weaknesses and failures factors are structure and limited vocabularies. The students are not able to compose their thoughts, ideas because they have limited number of words, limited 
patterns of sentences, and lack of motivation. They consider that writing is difficult.

There are two reasons behind the consideration that writing is difficult. Firstly, they do not know what topic to choose and when they have selected the topic, they do not know how to develop it into good writing. Secondly, the students consider that people who are able to write are people who have talent or natural gift for it. Leo (2007) made a small scale survey. He found that students' problem in writing are (1) limited vocabulary $(8 \%),(2)$ difficulty in organizing ideas

(16\%), (3) no ideas to write about (20\%), (4) no motivation to write (20\%), (5) and lack of confidence in grammar (36\%). Bereiter \& Scardamalia (1982) as state that, writing is a highly complex process; the writer not only must negotiate the rules and mechanics of writing, but also maintain a focus on important aspects of writing such as organization, form, and features, purposes and goals, audiences' need, perspectives, and evaluation of the communication between author and reader. The writer has also experienced this, he gets difficulties in organizing his ideas into good writing and he does not know how to produce details to give relevant evidences to support selected topics and organize them into effective writing.

It is expected that the students have to be able to write all kinds of writing as suggested by Elbow (2000): genre (e.g. poetry, fiction, nonfiction), modes (e.g. narration, description, argument), the elements in the writing process (e.g. generating, revising, copy-editing), parts of rhetoric (e.g. invention, arrangement, style), purposes (e.g. persuading, informing, entertaining), or even by topics or themes (science writing, religious writing, technical writing). There are so many kinds of text, and one of them is narrative. Narrative text is defined as literature written primarily to tell a story. Good narrative literature, which establishes or develops a conflict, addressees' common aspects of human existence. Narrative is not simply about entertaining the reader even though it generally does so. Narrative is also a powerful medium fro changing social opinions attitudes and some soap operas and televisions drama as narrative to raise topic issue and present their complexities and different perspectives in ways that are not possible in news reports and current affair program. Formally, narrative sequences people/characters in time and place.

According to McKeough, Palmer, Jarvey, and Bird (2007) that narrative features are:

a) Sequentiality. Story events occur in a sequence, linked by connecting words such as and, then, because, and but).

b) Particularity. Stories are about something in particular; extraneous events that do not relate to this particular something should not be included in the story.

c) Intentional states. Story characters' actions are motivated by their intentions (i.e., goals, desires, wants, and needs). Canonicity and breach. In stories, the expected order of things (i.e., the canon) is breached or violated, thus situating the story character in a dilemma.

The structure of narrative is generally more complex that the orientation and sequencing typical of recounting. Stories, for instance, bring a rather complex dimension into play more than simply sequencing a series of events, stories sequence to set up one or more complexities or problems. This narrative problem must be resolved, otherwise readers will get confused.

According to Gerot \& Wignell (1994) narrative is introduced to amuse, entertain and to deal with the actual or vicarious experience in different ways. It deals with the problematic events which lead to crisis or turn point of some kinds, which in turn to find a resolution. The generic (schematic) structure of narrative test are:

a) Orientation that is sets the scene and introduces the participants,

b) evaluation that is a stepping back to evaluate the light (optional),

c) complication that is a crisis arises,

d) resolution that is crisis is resolved for better or for worse, and

d) re-orientation that is optional included.

Besides the generic structures of narrative mention above, there are some typical linguistic realizations of narrative text: a) Material Process, b) The simple past, c) Location relation, and d) Circumstance of location. One of the most important things to consider solving this problem is by applying consultancy prewriting protocol technique. According to Urquhart and McIver (2005) a consultancy prewriting protocol technique is a structured process for helping a presenter thinks more expansively about a dilemma. 
Protocols provide a structured way for students to contribute their thoughts and ideas while creating the opportunity to listen to multiple voices. Protocols also serve as useful tools to temper dominant voices. Therefore, consultancy prewriting protocol technique has a significant effect to teaching language to students by which the students are freely contribute their thoughts and ideas through the writing process, as by using it the teacher provides a structure way for helping students to do the writing. Procedure is a way of doing something, especially the usual or correct way. The following is some procedure of implementing the consultancy prewriting protocol technique suggested by Urquhart and McIver (2005):

a) Prepare the question or questions you want your students to address in their discussion or set aside time for students to develop their own questions.

b) Review the steps of the protocol with students and ask for clarifying questions.

c) Divide the students into small groups.

d) Allow time for students to have their discussion.

e) Conclude the process by noting any suggestions that students make for future discussions.

\section{Research Question}

Based on the background of the study, the problem of the study is formulated in the form of a question as follows:

- 'Is the students' achievement in narrative writing improved if taught using consultancy prewriting protocol technique?"

\section{Significance of the Study}

The teaching of writing seems to be a very difficult task because it involves many aspects of the language namely: vocabulary, grammar, ideas, production, ideas organization, punctuation, and the writing rules. Thus, a best method, technique and approach should be applied in order that writing is not considered as a big burden to the teachers and the students. One of the strategies which can be applied in teaching writing is the consultancy prewriting protocol technique which enables English teachers and the students to write various narrative texts systematically.
This study is expected to be useful for teachers, students and other researchers. It is hoped that it will:

a) provide a writing technique to the English teachers to instruct the students during the writing process,

b) guide the students to write systematically by following every stage of the think sheet in the series of the writing process,

c) enable the students to write various writing types by following the consultancy prewriting protocol technique stages,

d) motivate the students to be a better writer,

e) contribute a real systematic form of think sheet in writing to the students and to other those who are interested in writing, and encourage other researchers to investigate other stages of the writing process.

\section{B. RESEARCH METHODOLOGY}

1. Research Design

The research method applied was the Classroom Action Research. Action research is a type of insider investigation by researcher in their own area as a focus for their study. The process of action research is reflective, deliberate, and systematic. According to Anderson, Herr and Nihlen (1994) stated that action research is directed toward an action or circle of actions that a researcher wants to take to address a situation. This is why the term "action" is used for this method of research.

According to Kemmis \& Teggart (1988) as quoted in Hughes, state that action research has three conditions that must be exist. Firstly, a project relate to a social practice, regarding as a form of technique action susceptible of improvement; secondly, it proceeds through a spiral of cycles of planning, acting (implementing plan), observing (systematically) and reflecting; thirdly, it involves those responsibility for the practice in each of the moment of the activity, widening participation in the project is gradually to include others affected by the practice, and maintaining the collaboration of the purposes. In addition, Anderson, et al. (1994) assert that action research enables teacher to build on informal observation and question. This is a way to bring intention to a conscious level of observation, to affirm or to improve practice, to systematize problem 
solving, or to support a teacher taking on a new task.

Based on the statement above it can be stated that action research aims to improve students' learning and the outcomes of teaching learning process. It is an approach to improve teaching practice. Moreover, it concerns to four steps namely; planning, action, observation and reflection.

This study applies the classroom action research with the single test design. It only uses a group of students to whom treatment is given, in order to make easier to control the cycles conducted in this research.

\section{Data Collection}

In collecting the data, writing test was used as the instrument. The students were tested by asking them to write narrative text based on the direction of the teacher. In scoring the students narrative text, the researcher used five components of scoring writing proposed by Reid (1993: 236-237). Beside the writing test, the researcher also used interview, questionnaire sheet, diary note, and observation sheet which were used when the researcher wanted to identify what was happening.

\section{Data Analysis}

Qualitative and quantitative data was used in this study. The qualitative data were used to describe the situation during the teaching process and the quantitative data were used to analyze the score of the students. By applying these designs, it was expected to get the satisfying result. The qualitative data were analyzed from interview sheet, questionnaire sheet, observation sheet, and diary note to describe the improvement of students' narrative writing. The quantitative data were collected and analyzed by computing the score of the writing test. The component of the writing test covers content, organization, vocabulary, language use, and mechanics. Therefore, by applying both of the data, it was expected that improvement in students' achievement in narrative writing through consultancy prewriting protocol technique would be achieved.

\section{a. The Quantitative Data}

The quantitative data were taken from the test results which had been carried out in two cycles and each cycle consists of 4 meetings. In cycle 1, pre-test was conducted to the students in the first meeting, in the second and the third meetings they were taught how to write narrative text by using consultancy prewriting protocol. In the fourth meeting, which was the end of the first cycle, a test (test I) was given to the students.

In cycle 2, the students were taught again by using consultancy prewriting protocol technique. At the end of cycle 2, the students were given test II to evaluate the students' achievement in narrative writing.

The research was conducted in six meeetings. The students were given a test at the end of each cycle. The students' narrative writing scores improved from test I in the first cycle to test II in the second cycle. It can be concluded that by using consultancy prewriting protocol technique, students' achievement in narrative writing kept improving from cycle 1 to cycle 2 .

The range of score improvement from cycle 1 to cycle 2 can be seen in the following table:

Table 1

Range of Score Improvement from Cycle 1 to Cycle 2

\begin{tabular}{ccc}
\hline Range & Frequency & Percentage \\
$21-30$ & 1 & $2,33 \%$ \\
$11-20$ & 40 & $93,02 \%$ \\
$0-10$ & 2 & $4,65 \%$ \\
\hline
\end{tabular}

There were significant improvements from the lowest and the highest scores of narrative writing within each test of each cycle. The comparison of students' scores in each test can be seen in the following table:

Table 2

The Comparison of Students' Narrative Writing Score

\begin{tabular}{|l|c|c|}
\hline \multicolumn{1}{|c|}{ Score } & Test I & Test II \\
\hline $\begin{array}{l}\text { The Highest } \\
\text { Score }\end{array}$ & 69 & 84 \\
\hline $\begin{array}{l}\text { The Lowest } \\
\text { Score }\end{array}$ & 51 & 67 \\
\hline
\end{tabular}


In test I (in cycle 1), the lowest score was 51 and the highest score was 69. In test II (cycle 2), the lowest score was 67 and the highest score was 84 . From the table above it can be found that there was a significant improvement of students' achievement in narrative writing.

The improvement of students' score can also be seen from the mean of the students' score in every test through this following formula:

$$
\bar{X}=\frac{\sum X}{N}
$$

$$
\text { Where: } \quad \begin{array}{ll}
\bar{X} & =\text { Mean of Score } \\
\sum X & =\text { Total of Students }
\end{array}
$$

score

$$
\mathrm{N}=\text { Number of students }
$$

The mean of test I:

$$
\begin{aligned}
& \bar{X}=\frac{\sum X}{N} \\
& \bar{X}=\frac{2640}{43} \\
& \bar{X}=61,39
\end{aligned}
$$

The mean of the test II:

$$
\begin{aligned}
& \bar{X}=\frac{\sum X}{N} \\
& \bar{X}=\frac{3292}{43} \\
& \bar{X}=76,58
\end{aligned}
$$

The indicator of successful achievement in this research was if there were at least $70 \%$ of the students got the score of $\geq 65$ in writing narrative text. The number of competent students in writing narrative text was calculated by applying this following formula:

$P=\frac{R}{T} \times 100 \%$
Where : $\quad \mathrm{P}=$ Percentage of students who got the score $\geq 65$

$$
\mathrm{R}=\text { Number of students who got }
$$

the $\geq 65$

$$
\mathrm{T}=\text { The total number of students }
$$

who took the test

The percentage of competent students in test I:

$$
\begin{aligned}
& P=\frac{R}{T} \times 100 \% \\
& P=\frac{12}{43} \times 100 \%=27,90 \%
\end{aligned}
$$

The percentage of competent students in test II:

$$
\begin{aligned}
& P=\frac{R}{T} \times 100 \% \\
& P=\frac{43}{43} \times 100 \%=100 \%
\end{aligned}
$$

In test I (first cycle), there was $27,90 \%$ of the number of students who got the score $\geq 65$. In test II (second cycle), there was $100 \%$ of number of students who got the score $\geq 65$. From test I to test II, there was significant improvement of students' achievement in narrative writing (from $27,90 \%$ to $100 \%$ ). It can be concluded that consultancy protocol technique could help students in improving their achievement in narrative writing.

b. The Qualitative Data

The qualitative data which were taken from the diary notes showed that the students' interest to learn narrative writing through consultancy prewriting protocol technique kept increasing even some problem occurred in the class such as the students didn't pay attention well while they were taught by using the consultancy prewriting protocol. The interview sheets showed that most of the students had never been taught to write narrative text by using the consultancy prewriting protocol technique. The questionnaire sheets showed their good response to the technique in teaching learning process. The observation sheets showed that in the first cycle they were in low desire, but after they were 
informed again about the purpose of the research, they gave more desire and attention, so in the second cycle they were very active and enthusiastic in writing their narrative text by using the consultancy prewriting protocol technique. Even though some of the students still found difficulties to write the narrative text but at last it became easier for them to write the narrative text well.

\section{FINDINGS AND DISCUSSION}

The result indicated that there was an improvement on the students' narrative text writing achievement through consultancy prewriting protocol technique. It was supported by the fact that the mean of the score in every test increased. The mean in the pre-test was 52,51, the mean of test I (cycle 1) was 61,39 and the mean of the test II (cycle 2) was 76,58 .

The qualitative data were taken from interview sheet, diary notes, questionnaire and observation sheet which showed that students' participation in this study increased from meeting to meeting. Based on the interview, the students admitted that their English teacher had never used consultancy prewriting protocol technique in teaching writing skill especially in narrative writing. These data described the students' attention, enthusiastic, responses and the participation was good during the research process.

\section{CONCLUSION AND}

\section{RECOMMENDATION}

After analyzing the data, it was found out that the students' score increased from the first cycle to the second cycle. The mean of the students' score in test I was 61,39 then it was improved in test II became 76,58. It means that the mean of the students' score from the tests improved 15,19. From the data it can be concluded that consultancy prewriting protocol tecgnique can help students' achievement in narrative wrtiting.

It was also found that the students no longer have difficulties in writing narrative text since consultancy prewriting protocol technique can help them in narrative writing. The technique help them to elaborate the ideas to write about the topic they want to write. By using consultancy prewriting protocol technique, the students finally found that writing narrative text is not so difficult as they thought and even it can be fun because the technique help them to share and elaborate ideas. Therefore, it can be concluded that consultancy prewriting protocol technique can improve students' achievement in narrative writing.

The results of this study shows that the use of consultancy prewriting protocol technique in writing skill can improve the students' achievement in narrative writing. These following suggestions are offered:

- To English teacher, it is better to use the consultancy prewriting protocol technique in teaching writing skill to the students because it will be easier for the students to write a text, especially a narrative text. This technique makes the students share ideas in a group and elaborate the ideas into writing individually.

- To the students, it is suggested to practice writing more often by using consultancy prewriting protocol technique since it can improve the students' achievement in narrative writing.

- For all the readers, this research will bring you to good understanding of writing the narrative text because by using this technique people will not get stuck in writing narrative text. They will always know what to write since the technique allow them to share ideas.

\section{E. REFERENCES}

[1] Anderson, G. L., Herr, K., \& Nihlen, A. S. (1994). Studying your own school: An educator's guide to qualitative practitioner research. Thousand Oaks, California: Corwin Press.

[2] Bradford, J. (2019, January 29). Why writing ability is the most important skill in business (and how to acquire it). Forbes Agency

Council. Retrieved from. https://www.forbes.com/sites/forbesagencyc ouncil/2019/01/29/why-writing-ability-isthe-most-important-skill-in-business-andhow-to-acquire-it/\#7416666f2fdf

[3] Elbow, P. (2000). Everyone Can Write: Essays toward a hopeful theory of writing and teaching writing. New York: Oxford University Press. 
[4] Gerot \& Wignell. 1994. Making Sense of Functional Grammar. Cammeray, NSW: Antipodian Educational Euterprises.

[5] Graham, S., Fitzgerald, J., Friedrich, L. D., Kim., J. S., \& Olson, C. B. (2016). Teaching Secondary Students to Write Effectively. Arizona: Institute of Education Sciences.

[6] Graham, S., \& Harris, K. R. (2000). The role of self-regulation and transcription skills in writing and writing development. Educational Psychologist, 35:1, 3-12, DOI: 10.1207/S15326985EP3501_2

[7] Graham, S., MacArthur, C. A., \& Fitzgerald, J. (Eds.). (2007). Solving problems in the Teaching of Literacy. Best practices in writing instruction. New York, NY, US: Guilford Press.

[8] Harmer, J. 2004. How to Teach Writing. Harlow : Pearson Education.

[9] Kemmis, S. \& Teggart. 1995. http://www.web.net/ robrien/papers/arfinal. html. An Over View of thMethodological

[10] Approach of Action Research. Accessed on February $9^{\text {th }}, 2009$.

[11] Leo, S. 2007. English for Spesific Purpose: Narrative text Writing. Yogyakarta: CV Andi Offset.

[12] McKeough, A., Palmer, J., Jarvey, M., \& Bird, S. (2007). Best narrative writing practices when teaching from a development framework. In Graham, S., MacArthur, C. A., \& Fitzgerald, J. Best Practices in Writing Instruction. New York: Guilford Press.

[13] Reid, J, M. 1993. Teaching ESL Writing. United States: Prentice Hall Regents. 